\title{
ANEMIA DEFISIENSI BESI DAN INDEKS MASSA TUBUH TERHADAP SIKLUS MENSTRUASI REMAJA
}

\author{
Sri Hidayati L1, Estri Kusumawati ${ }^{2}$, Nova Lusiana ${ }^{3}$, Ika Mustika ${ }^{4}$ \\ 1,2,3,4 Universitas Islam Negeri Sunan Ampel Surabaya \\ Email: ikamustika@uinsby.ac.id
}

DOI : $\underline{10.24252 / \text { kesehatan.v12i1.7157 }}$

\begin{abstract}
Abstrak
Prevalensi anemia di dunia adalah $46 \%$ menurut WHO dan 68 \% wanita berdasarkan Riset Kesehatan Dasar mengalami haid tidak teratur. Gangguan siklus menstruasi berdampak meningkatnya risiko penyakit kanker dan kardiovaskuler. Anemia dan status gizi merupakan salah satu faktor yang dapat mempengaruhi menstruasi. Penelitian bertujuan untuk mengetahui pengaruh anemia dan Indeks Massa Tubuh (IMT) Terhadap siklus menstruasi remaja putri. Jenis penelitian ini adalah analitik observasional dengan rancangan penelitian kohort. Penelitian ini menggunakan data primer. Pengumpulan data awal meliputi pengukuran berat badan dan tinggi badan, pengambilan sampel darah dan kuesioner. Untuk penentuan anemia dilakukan dengan pemeriksaan sampel darah dengan $\mathrm{Hb}$ Sahli. Penentuan siklus menstruasi dengan pengisian kuesioner tentang menstruasi selama 3 bulan. Analisis data menggunakan program komputer dengan derajat kepercayaan 95\%. Analisis bivariat menggunakan chi square dengan a 0,05. Regresi logistik ganda digunakan untuk melakukan analisis multivariat. Hasil Penelitian menunjukkan 15 \% remaja putri mengalami anemia,48,3\% indeks massa tubuh tidak normal dan $46,7 \%$ siklus menstruasi tidak normal. Tidak terdapat pengaruh anemia dan indeks massa tubuh terhadap menstruasi remaja putri. Berdasarkan hasil penelitian maka remaja putri perlu melakukan pemeriksaan kadar $\mathrm{Hb}$ secara rutin untuk mencegah anemia secara dini dan mengkonsumsi makanan bergizi yang sangat dibutuhkan pada saat menstruasi.
\end{abstract}

\section{Kata Kunci: Anemia; Indeks Massa Tubuh; Siklus Menstruasi}

\begin{abstract}
The prevalence of anemia in the world is $46 \%$ according to WHO and $68 \%$ of women based on Riset Kesehatan Dasar experience irregular menstruation. Menstrual cycle disorders have an increased risk of cancer and cardiovascular disease. Anemia and nutritional status is one of the factors that can affect menstruation. The study was to determine the effect of anemia and Body Mass Index (BMI) on the menstrual cycle of young women. This type of research is observational analytic with a cohort study design. This study uses primary data. Initial data collection included measurements of body weight and height, blood sampling and questionnaires. The determination of anemia was carried out by examining blood samples with $\mathrm{Hb}$ Sahli. Determination of the menstrual cycle by filling out a questionnaire about menstruation for 3 months. Data analysis using a computer program with a 95\% confidence level. Bivariate analysis using chi square with a 0.05. Multiple logistic regression is used to conduct multivariate analysis. The results showed $15 \%$ of female adolescents had anemia, $48.3 \%$ of body mass index was abnormal and $46.7 \%$ of menstrual cycle was abnormal. There is no influence of anemia and body mass index on menstruation for young women. Based on the results of the study, young women
\end{abstract}


need to check $\mathrm{Hb}$ levels regularly to prevent anemia early and consume nutritious foods that are needed during menstruation.

\section{Keywords: Anemia; Body Mass Index; Menstrual}

\section{PENDAHULUAN}

Perempuan dalam kehidupannya akan mengalami siklus menstruasi yang terjadi secara periodik sejak menarche hingga menopause. Siklus menstruasi normalnya berlangsung antara 21 - 35 hari dengan rata-rata siklus 28 hari. Lama menstruasi biasanya 3 - 5 hari. Lama menstruasi pada setiap perempuan biasanya tetap (Wiknjosastro, 2012). Berdasarkan data hasil Riset Kesehatan Dasar (Rikesdas) tahun 2010 didapatkan bahwa sebanyak $68 \%$ wanita usia 1059 tahun mengalami haid yang tidak teratur (RISET KESEHATAN DASAR, 2010). Hasil penelitian yang dilakukan Santi terhadap pasien yang datang berobat ke Klinik UIN Sunan Ampel dari tahun 2015-2017 menunjukkan bahwa sebanyak 192 pasien wanita mengalami gangguan menstruasi. Gangguan menstruasi tersebut berupa gangguan siklus/pola menstruasi, lama menstruasi, serta gangguan lainnya (Santi \& Pribadi, 2018).

Siklus menstruasi normalnya berlangsung antara 21 - 35 hari dengan rata-rata siklus 28 hari. Lama menstruasi biasanya 3 - 5 hari. Lama menstruasi pada setiap perempuan biasanya tetap (Wiknjosastro, 2012). Siklus menstruasi yang normal tersebut menunjukkan bahwa organ reproduksi dan sistem hormonal perempuan tersebut normal dan tidak mengalami gangguan. Namun, pada kenyataannya tidak sedikit perempuan yang mengalami gangguan pada siklus menstruasinya.

Berdasarkan data hasil Riset Kesehatan Dasar (Rikesdas) didapatkan bahwa sebanyak 68\% wanita usia 10-59 tahun mengalami haid yang tidak teratur (RISET KESEHATAN DASAR, 2013). Hasil penelitian yang dilakukan Santi (2017) terhadap pasien yang datang berobat ke Klinik UIN Sunan Ampel dari tahun 2015-2017 menunjukkan bahwa sebanyak 192 pasien wanita mengalami gangguan menstruasi (Santi \& Pribadi, 2018). Gangguan menstruasi tersebut berupa gangguan siklus/pola menstruasi, lama menstruasi, serta gangguan lainnya. Gangguan siklus menstruasi dapat berupa polimenorea, oligomenorea, amenorea, hipominorea serta hiperminorea. Pada polimenorea terjadi siklus haid yang pendek, kurang dari 21 hari, sedangkan oligomenorea terjadi siklus haid yang panjang lebih dari 35 hari. Gangguan menstruasi amenorea, siklus menstruasi memanjang hingga tidak terjadi haid minimal dalam waktu 3 bulan berturut-turut. Pada hipomenorea, terjadi perdarahan menstruasi yang lebih sedikit dari biasanya, sedangkan hipermenorea terjadi perdarahan yang lebih banyak dan lebih lama dari normalnya (Wiknjosastro, 2012).

Penelitian yang dilakukan Santi selama tahun 2015-2017 di klinik Pratama UIN Sunan Ampel Surabaya menunjukkan bahwa terdapat 192 orang yang mengalami gangguan menstruasi. Gangguan menstruasi yang banyak terjadi adalah hipermenorea/menorhagia dan dismenorea. (Santi \& Pribadi, 2018).

Gangguan siklus menstruasi tersebut dapat menjadi indikator untuk menggambarkan perubahan fisiologis dari fungsi ovarium dan hormonal, dan telah dihubungkan dengan 
peningkatan resiko penyakit seperti kanker payudara, kanker ovarium, penyakit kardiovaskuler, diabetes dan fraktur. Gangguan menstruasi tersebut dapat berdampak menurunnya kualitas hidup seseorang serta menimbulkan beban secara finansial, gangguan menstruasi dapat dipengaruhi oleh berat badan, frekuensi olahraga, aktivitas fisik, diet, paparan lingkungan, kondisi kerja, sinkronisasi proses menstruasi, dan gangguan endokrin (Mahitala, 2015).

Menurut Kusmiran E. (2011), gangguan menstruasi dapat dipengaruhi oleh berat badan, frekuensi olahraga, aktivitas fisik, diet, paparan lingkungan, kondisi kerja, sinkronisasi proses menstruasi, dan gangguan endokrin (Mahitala, 2015). Penelitian yang dilakukan Puspita D menunjukkan bahwa status gizi perempuan dapat menyebabkan perubahan hormon yang berhubungan dengan gangguan fungsi hipotalamus. Perubahan hormon tersebut berpengaruh terhadap siklus menstruasi pada perempuan (Puspita, 2014). Menurut Basri Aramiko yang meneliti tentang hubungan siklus menstruasi dengan status gizi siswi, didapatkan hasil siswi dengan menstruasi normal maka status gizinya pun normal. Sistem hormon terkait dengan status gizi, tidak jarang perempuan dengan status gizi normal tetapi siklus menstruasinya tidak normal. Hal tersebut dapat disebabkan sindroma polikistik ovarium, kelainan uterus, kontrasepsi, penyakit kronis dan faktor psikologis (Aramico, Siketang, \& Nur, 2016). berdasarkan penelitian Rakhmawati (2013), kejadian gangguan silus menstruasi pada wanita yang mengalami obesitas 1,89 kali lebih besar dibandingkan dengan wanita dengan status gizi normal sedangkan wanita yang mengalami stress 2 kali lebih besar dibandingkan dengan subjek yang tidak mengalami stress. Gangguan yang paling sering terjadi pada obesitas adalah oligomenore, sedangkan gangguan yang sering terjadi akibat stress adalah polimenore. (Rakhmawati \& Dieny, 2013).

Anemia karena defisiensi besi merupakan masalah gizi yang paling umum dialami oleh seorang wanita, terutama pada remaja putri. Menurut WHO (2011), remaja putri merupakan kelompok resiko tinggi yang mengalami anemia dibandingkan remaja putra dimana kebutuhan zat besi memuncak pada umur 14-15 tahun, sedangkan remaja putra satu atau dua tahun berikutnya (Silalahi, Aritonang, \& Ashar, 2016). Menurut Briawan dalam Yunarsih (2014) prevalensi anemia didunia diperkirakan $46 \%$, sedangkan dari laporan Depkes prevalensi anemia pada remaja putri di Indonesia $30 \%$ dan remaja pria $21 \%$. Menurut Permaesih menyatakan prevelensi anemia pada remaja sebesar $25,5 \%$, dijumpai pada remaja laki-laki $21 \%$ dan perempuan $30 \%$. Sebanyak $27,1 \%$ remaja menderita anemia berdomisili di pedesaan dan $2,6 \%$ di perkotaan.

Penelitian Kristianti (2014), menunjukkan bahwa anemia dapat mempengaruhi siklus menstruasi perempuan. Kadar hemoglobin yang cukup atau tidak anemia akan membantu keteraturan siklus menstruasi. Sebaliknya apabila terjadi kekurangan zat besi dalam tubuh dapat menyebabkan kadar haemoglobin rendah, yang dapat menimbulkan banyak komplikasi pada perempuan. Hal tersebut terjadi karena rendahnya kadar haemoglobin pada tubuh mengakibatkan kurangnya suplay oksigen ke hipotalamus. Namun, secara keseluruhan belum dikaji dengan lengkap tentang pengaruh anemia dan indeks massa tubuh terhadap siklus menstruasi. (Kristianti \& Wibowo, 2014).

Allah SWT berfirman melalui surat dalam surat Thaha ayat 81 tentang makanan dari rezeki yang baik dan larangan untuk jangan melampaui batas. Pada ayat tersebut Allah SWT 
memerintahkan kita untuk memilih makanan yang baik, tidak berlebihan dan seimbang agar tidak muncul suatu penyakit, termasuk penyakit yang berhubungan dengan kesehatan reproduksi. Penelitian yang dilakukan Puspita D menunjukkan bahwa status gizi perempuan dapat menyebabkan perubahan hormon yang berhubungan dengan gangguan fungsi hipotalamus. Perubahan hormon tersebut berpengaruh terhadap siklus menstruasi pada perempuan. Menurut Anggarini dan Chayaningrum pada tahun 2012 dalam Puspita seorang wanita yang mengalami kekurangan atau kelebihan gizi akan berdampak pada penurunan fungsi hipotalamus yang tidak memberikan rangsangan hipofisis anterior untuk menghasilkan folikel stimulating hormone (FSH) yang berfungsi untuk merangsang pertumbuhan folikel pada sel telur, sedangkan luteinizing hormone (LH) berfungsi untuk mematangkan sel telur yang akan dibuahi. Apabila produksi FSH dan LH terganggu maka siklus menstruasi akan terganggu (Puspita, 2014). Menurut penelitian yang dilakukan Kaimudin terdapat hubungan antara status gizi dengan kejadian anemia pada remaja putri. Hal tersebut dikarenakan konsumsi makanan yang tidak memenuhi prinsip gizi seimbang, sehingga asupan nutrisi yang diperlukan tidak terpenuhi (Nur Ia Kaimudin et al., 2017).

Salah satu cara untuk menilai status gizi seseorang adalah dengan mengukur Indeks massa tubuh (IMT). Pengukuran dan penilaian status gizi dengan menggunakan IMT dilakukan dengan rumus matematis berat badan (dalam kilogram) dibagi dengan kuadrat tinggi badan (dalam meter). Hasil dari pengukuran IMT dapat digunakan untuk mengetahui apakah terjadi kekurangan dan kelebihan status gizi seseorang. Rumus IMT ini hanya dapat diterapkan pada seseorang yang berusia 19 - 70 tahun, bukan ibu hamil atau menyusui. Pengukuran dapat digunakan terutama jika pengukuran tebal lipatan kulit tidak dapat dilakukan atau nilai bakunya tidak tersedia.

Berdasarkan latar belakang tersebut, peneliti tertarik untuk melakukan penelitian tentang pengaruh anemia defisiensi besi dan indeks massa tubuh dengan siklus menstruasi pada remaja putri. Tujuan penelitian ini adalah untuk mengetahui pengaruh anemia defisiensi besi dan indeks massa tubuh terhadap siklus menstruasi remaja putri

\section{METODOLOGI PENELITIAN}

Jenis penelitian ini adalah analitik observasional dengan rancangan penelitian kohort. Penelitian ini dilakukan di laboratorium terintegrasi UIN Sunan Ampel Surabaya. Penelitian ini dilaksanakan pada bulan Juli - Oktober 2018. Penelitian ini menggunakan data primer. Pengumpulan data awal meliputi pengukuran berat badan dan tinggi badan, pengambilan sampel darah dan kuesioner. Data Primer penentuan Indeks Massa Tubuh (IMT) dilakukan dengan konversi penimbangan berat badan dan hasil pengukuran tinggi badan. Untuk penentuan anemia dilakukan dengan pemeriksaan sampel darah dengan $\mathrm{Hb}$ Sahli. Jika kadar $\mathrm{Hb}$ yang didapat $<12 \mathrm{mmHg}$ maka dikategorikan anemia, tetapi jika hasil kadar $\mathrm{Hb} \geq 12 \mathrm{mmHg}$ maka dikategorikan tidak anemia atau normal. Penentuan siklus menstruasi dengan pengisian kuesioner tentang menstruasi selama 3 bulan ke depan.

Instrument penelitian menggunakan easy touch, timbangan, pengukur tinggi badan dan lembar kuesioner. Lebar kuesioner untuk mengetahui siklus menstruasi pada remaja putri. Populasi dalam penelitian ini adalah mahasiswi prodi biologi fakultas Sains dan teknologi. Tehnik sampling yang digunakan dalam penelitian ini adalah purposive sampling yaitu remaja 
putri yang sudah mengalami menstruasi. Jumlah sampel yang digunakan dalam penelitian ini sejumlah 60 sampel. Variabel dalam penelitian ini terdiri dari variable bebas dan variabel terikat. Variabel bebas dalam penelitian ini adalah anemia defisiensi besi dan indeks massa tubuh, sedangkan variabel terikat dalam penelitian ini adalah siklus menstruasi.

Analisis data menggunakan program komputer dengan derajat kepercayaan 95\%. Analisis bivariat menggunakan chi square dengan a 0,05. Regresi logistik ganda digunakan untuk melakukan analisis multivariat. Sebelum, dilakukan uji statistik, maka dilakukan uji prasyarat yaitu uji normalitas, homogenitas, liniearitas dan multikolonieritas.

Data yang diperoleh akan di analisis menggunakan uji chi square untuk melihat apakah ada hubungan antara status anemia dengan siklus menstruasi dan hubungan antara IMT dengan siklus menstruasi remaja putri. Selanjutnya akan diuji lagi dengan menggunakan regresi logistik ganda untuk melihat adakah pengaruh dua variabel independen secara bersamaan terhadap variabel dependen. Dalam hal ini dilakukan uji regresi logistik ganda pada status anemia dan IMT terhadap siklus menstruasi remaja putri.

\section{HASIL DAN PEMBAHASAN}

Hasil penelitian ini bertujuan untuk mengetahui pengaruh status anemia terhadap siklus menstruasi remaja putri dan pengaruh Indeks Massa Tubuh (IMT) terhadap siklus menstruasi remaja putri didapatkan sebagai berikut :

\section{a. Status Anemia}

Tabel 1 Hasil Kadar Haemoglobin

\begin{tabular}{ccc}
\hline Kadar Hb & $\mathrm{N}$ & $\%$ \\
\hline$<12 \mathrm{mmHg}$ & 9 & 15,0 \\
$\geq 12 \mathrm{mmHg}$ & 51 & 85,0 \\
Total & 60 & 100 \\
\hline
\end{tabular}

Sumber : Data Primer, 2018.

Berdasarkan tabel 1 menunjukkan bahwa terdapat $9(15,0 \%)$ sampel yang memiliki kadar $\mathrm{Hb}<12 \mathrm{mmHg}$ sehingga status anemia yaitu mengalami anemia dan terdapat 51 $(85,0 \%)$ sampel memiliki kadar $\mathrm{Hb} \geq 12 \mathrm{mmHg}$ sehingga status anemia yaitu tidak mengalami anemia.

b. Indeks Massa Tubuh (IMT)

Tabel 2 Variabel Indeks Massa Tubuh (IMT)

\begin{tabular}{ccc}
\hline IMT & N & $\%$ \\
\hline Normal & 31 & 51,7 \\
Tidak Normal & 29 & 48,3 \\
Total & 60 & 100
\end{tabular}

Sumber : Data Primer, 2018.

Berdasarkan tabel 2 menunjukkan bahwa terdapat 31 sampel yang memiliki IMT normal (51,7\%) dan terdapat 29 sampel (48,3\%) yang memiliki IMT tidak normal.

\section{c. Siklus Menstruasi}

Tabel 3 Variabel Siklus Menstruasi 


\begin{tabular}{ccc}
\hline Siklus Menstruasi & N & $\%$ \\
\hline Normal & 32 & 53,3 \\
Tidak Normal & 28 & 46,7 \\
Total & 60 & 100 \\
\hline
\end{tabular}

Sumber : Data Primer, 2018.

Berdasarkan tabel 3 menunjukkan bahwa terdapat 32 sampel yang memiliki siklus menstruasi normal (53,3\%) dan terdapat 28 sampel (46,7\%) yang memiliki siklus menstruasi tidak normal.

d. Hasil penelitian berdasarkan variabel status anemia dan siklus menstruasi dapat dilihat dari tabel berikut :

Tabel 4 Analisis Bivariat berdasarkan Status Anemia dan Siklus Menstruasi

\begin{tabular}{cccccccc}
\hline Status Anemia & \multicolumn{3}{c}{ Siklus Menstruasi } & \multicolumn{2}{l}{ Jumlah } & P value \\
& \multicolumn{2}{c}{ Tidak Normal } & \multicolumn{2}{c}{ Normal } & & & \\
\hline & $\mathrm{N}$ & $\%$ & $\mathrm{~N}$ & $\%$ & $\mathrm{~N}$ & $\%$ & \\
Ya & 5 & 55,6 & 4 & 44,4 & 9 & 15,0 & 0,721 \\
Tidak & 23 & 45,1 & 28 & 54,9 & 51 & 85,0 & \\
Jumlah & 28 & 46,7 & 32 & 53,3 & 60 & 100,0 & \\
\hline
\end{tabular}

Sumber : Data Primer, 2018.

Pada tabel 4 menunjukkan bahwa dari 9 sampel yang mengalami anemia terdapat 5 orang $(55,6 \%)$ yang memiliki siklus menstruasi tidak normal dan siklus menstruasi normal sebanyak 4 orang $(44,4 \%)$. Sedangkan sampel yang tidak mengalami anemia. Sedangkan dari 51 sampel yang tidak mengalami anemia, terdapat 23 orang $(45,1 \%)$ yang memiliki siklus men-struasi tidak normal, dan sebanyak 28 orang $(54,9 \%)$ yang memiliki siklus menstruasi normal. Hasil analisis statistik diperoeh nilai $p=0,721$ ( $\alpha>$ $0,05)$, ini berarti Ho diterima sehingga tidak ada hubungan antara status anemia dengan sikus mentruasi.

e. Hasil penelitian berdasarkan variabel penelitian Indeks Massa Tubuh dan siklus menstruasi dapat dilihat dari tabel berikut :

Tabel 5 Analisis bivariat berdasarkan Indeks Massa Tubuh dan Siklus Menstruasi

\begin{tabular}{cccccccc}
\hline IMT & \multicolumn{3}{c}{ Siklus Menstruasi } & \multicolumn{2}{c}{ Jumlah } & P value \\
& \multicolumn{2}{c}{ Tidak Normal } & \multicolumn{2}{c}{ Normal } & & & \\
\hline & $\mathrm{N}$ & $\%$ & $\mathrm{~N}$ & $\%$ & $\mathrm{~N}$ & $\%$ & \\
Kurang & 13 & 44,8 & 16 & 55,2 & 29 & 48,3 & \\
Normal & 15 & 48,4 & 16 & 51,6 & 31 & 51,7 & 0,986 \\
Jumlah & 28 & 46,7 & 32 & 53,3 & 60 & 100,0 & \\
\hline
\end{tabular}

Sumber : Data Primer, 2018.

Pada tabel 5 menunjukkan bahwa dari 29 sampel yang termasuk IMT kurang terdapat 13 orang $(44,8 \%)$ yang memiliki siklus menstruasi tidak normal dan siklus menstruasi normal sebanyak 16 orang $(55,2 \%)$. Sedangkan dari 31 sampel yang tidak mengalami anemia, terdapat 15 orang $(48,4 \%)$ yang memiliki siklus menstruasi tidak normal, dan sebanyak 16 orang $(51,6 \%)$ yang 
memiliki siklus menstruasi normal. Hasil analisis statistik diperoleh nilai $p=0,986(\alpha>0,05)$, ini berarti Ho diterima sehingga tidak ada hubungan antara IMT dengan siklus menstruasi.

\section{f. Analisis Regresi Logistik}

Analisis regresi digunakan untuk mempelajari pengaruh variabel bebas (independent variable) terhadap variabel tergantung (dependent variable). Dari analisis ini, juga akan diperoleh model terbaik (fit) yang dapat menggambarkan pengaruh variabel bebas dan variabel tergantung. Dalam penelitian ini dapat diketahui pengaruh variabel status anemia dan IMT terhadap siklus menstruasi (multivariate case) atau biasa disebut dengan Regresi Logistik Ganda.

Dari hasil analisis regresi logistik didapatkan nilai signifikan $p$ value $=0,563>0,05$ untuk variabel status anemia dan nilai signifikan $\mathrm{p}$ value $=0,948>0,05$ untuk variabel IMT, maka dapat disimpulkan bahwa Ho diterima atau Ha ditolak artinya kedua variabel tersebut tidak ada pengaruh terhadap siklus menstruasi remaja putri.

Hasil penelitian menunjukkan bahwa kadar Hemoglobin berdasarkan pemeriksaan kadar hemoglobin dengan Easy Touch yaitu sebanyak 9 sampel (15,0\%) yang memiliki kadar $\mathrm{Hb} \leq$ $11,5 \mathrm{gr} \%$ dan terdapat 51 sampel $(85,0 \%)$ yang memiliki kadar $\mathrm{Hb}>11,5 \mathrm{gr} \%$. Hal ini menunjukkan angka kejadian anemia pada remaja masih cukup tinggi.

Anemia pada remaja putri adalah keadaan kadar haemoglobin dalam darah kurang dari normal dengan nilai $\mathrm{Hb}$ normal menurut WHO $12 \mathrm{gr} / \mathrm{dl}$. Masalah gizi remaja merupakan kelanjutan dari masalah gizi pada usia anak, meskipun asupan kalori dan protein terpenuhi elemen lain seperti besi, kalsium dan beberapa vitamin ternyata masih kekurangan. Menurut Aramico (2016) terdapat hubungan antara siklus menstruasi dengan status gizi siswi, siswi dengan menstruasi normal maka status gizinya pun normal. Sistem hormon terkait dengan status gizi, tidak jarang perempuan dengan status gizi normal tetapi siklus menstruasinya tidak normal. Hal tersebut dapat disebabkan sindroma polikistik ovarium, kelainan uterus, kontrasepsi, penyakit kronis dan faktor psikologis (Aramico dkk., 2016). Menurut Tita (2012) rerata kadar $\mathrm{Hb}$ remaja putri yang mempunyai siklus menstruasi normal lebih tinggi dibandingkan kadar $\mathrm{Hb}$ Remaja putri dengan pola siklus menstruasi tidak normal. Protein nabati di dalam tubuh membutuhkan vitamin B 12 untuk mencegah dari anemia, lemas, gangguan asam urat dan penurunan fungsi otak. Selain itu vitamin B 12 membantu penyerapan kandungan zat besi dalam tubuh yang dapat menyebabkan anemia. Anemia sering terjadi pada remaja, remaja cenderung untuk menjaga penampilan dengan menghindari kenaikan badan yang berlebihan. Keadaan tubuh yang tidak sesuai dengan harapan membuat remaja melakukan diet. Remaja saat ini lebih banyak melakukan diet dengan mengurangi asupan karbohidrat. Masalahnya, remaja hanya memikirkan agar berat badannya turun tanpa memperhatikan apakah yang mereka lakukan pola hidup sehat atau tidak. Sejak dahulu di dalam masyarakat masih banyak yang menganggap bahwa wajah yang cantik dan tubuh yang langsing akan memiliki daya Tarik lebih tinggi dibandingkan yang memiliki tubuh besar. Akhirnya hal ini menyebabkan, remaja terutama putri berlomba-lomba melakukan diet. Akibatnya, asupan nutrisi tidak terpenuhi dan mudah terkena anemia. Selain itu, remaja putri yang telah memasuki masa pubertas akan mengalami menstruasi setiap bulan yang menyebabkan mudah terkena anemia. 
Berdasarkan hasil penelitian menunjukkan bahwa dari 9 sampel yang mengalami anemia terdapat 5 orang $(55,6 \%)$ yang memiliki siklus menstruasi tidak normal dan siklus menstruasi normal sebanyak 4 orang $(44,4 \%)$. Sedangkan sampel yang tidak mengalami anemia. Sedangkan dari 51 sampel yang tidak mengalami anemia, terdapat 23 orang $(45,1 \%)$ yang memiliki siklus menstruasi tidak normal, dan sebanyak 28 orang $(54,9 \%)$ yang memiliki siklus menstruasi normal. Hasil analisis statistik diperoleh nilai $p=0,721(\alpha>0,05)$, ini berarti Ho diterima sehingga tidak ada hubungan antara status anemia dengan siklus menstruasi.

Hal ini tidak sesuai dengan penelitian yang dilakukan Tita pada tahun 2012 yang menyatakan bahwa rerata kadar $\mathrm{Hb}$ remaja putri yang mempunyai siklus menstruasi normal lebih tinggi dibandingkan kadar $\mathrm{Hb}$ Remaja putri dengan pola siklus menstruasi tidak normal. Protein nabati di dalam tubuh membutuhkan vitamin B 12 untuk mencegah dari anemia, lemas, gangguan asam urat dan penurunan fungsi otak. Selain itu vitamin B 12 membantu penyerapan kandungan zat besi dalam tubuh yang dapat menyebabkan anemia.

Dalam penelitian Sayes (2011) prevalensi anemia defisiensi di tingkat universitas terhadap mahasiswi di universitas King Abdul Aziz didapatkan 23,9 \% mahasiswi mengalami anemia defisiensi besi diantara mahasiswi yang tampak sehat. Ditemukan juga adanya korelasi yang signifikan antara anemia dengan asupan gizi dan olahraga (Sayes, 2011).

Menurut Grooms dkk (2013) Remaja mengalami peningkatan risiko anemia karena pertumbuhan yang cepat dan peningkatan massa otot. Mahasiswi dengan perdarahan menstruasi berat beresiko lebih besar mengalami anemia. Remaja putri memiliki kebutuhan zat besi untuk mengimbangi kehilangan darah menstruasi dan pertumbuhan yang meningkat (Grooms dkk., 2013). Berdasarkan penelitian Rakhmawati (2013) Kejadian gangguan siklus menstruasi pada wanita yang mengalami obesitas 1,89 kali lebih besar dibandingkan dengan wanita dengan status gizi normal sedangkan wanita yang mengalami stress 2 kali lebih besar dibandingkan dengan subjek yang tidak mengalami stress. Gangguan yang paling sering terjadi pada obesitas adalah Oligomenore sedangkan gangguan yang sering terjadi akibat stress adalah polimenore. (Rakhmawati \& Dieny, 2013).

Kadar hemoglobin seseorang dipengaruhi oleh jenis kelamin, usia, aktivitas fisik, pola hidup dan komposisi tubuh yang berhubungan dengan status gizi (Zufrianingrum, 2016). Kecukupan Besi dalam Tubuh menjadi indikator penting yang menentukan kadar hemoglobin dalam darah. Besi digunakan sebagai bahan baku untuk memproduksi hemoglobin, sehingga anemia gizi besi akan menyebabkan terbentuknya sel darah merah yang lebih kecil dan kandungan hemoglobin yang rendah. Kecukupan besi yang direkomendasikan adalah jumlah minimum besi yang berasal dari makanan yang dapat menyediakan cukup besi untuk setiap individu yang sehat pada 95\% populasi, sehingga dapat terhindar kemungkinan anemia kekurangan besi (Zarianis, 2006). Selain itu, penggunaan alat untuk mengukur anemia juga berpengaruh terhadap hasil kadar $\mathrm{Hb}$. Berdasarkan hasil penelitian Kusumawati dkk. (2018) menunjukkan terdapat perbedaan hasil pengukuran kadar $\mathrm{Hb}$ dengan menggunakan $\mathrm{Hb}$ sahli dan easy touch. Pada penelitian ini menggunakan alat easy touch yang memiliki sensitifitas lebih tinggi (Kusumawati, Lusiana, Mustika, Hidayati, \& Andyarini, 2018).

Pada tabel 5 menunjukkan bahwa dari 29 sampel yang termasuk IMT kurang terdapat 13 orang $(44,8 \%)$ yang memiliki siklus menstruasi tidak normal dan siklus menstruasi normal sebanyak 
16 orang $(55,2 \%)$. Sedangkan dari 31 sampel yang tidak mengalami anemia, terdapat 15 orang $(48,4 \%)$ yang memiliki siklus menstruasi tidak normal, dan sebanyak 16 orang $(51,6 \%)$ yang memiliki siklus menstruasi normal. Hasil analisis statistik diperoleh nilai $p=0,986(\alpha>0,05)$, ini berarti Ho diterima sehingga tidak ada hubungan antara IMT dengan siklus menstruasi.

Hasil penelitian yang dilakukan oleh Yana Aurora Pradhita menyebutkan bahwa tidak terdapat hubungan yang berarti antara siklus menstruasi dengan IMT dan presentase lemak tubuh. Hasil penelitian dengan menggunakan uji chi-square menunjukkan hasil bahwa sebagian besar responden memiliki indeks massa tubuh (IMT) dan presentase lemak tubuh normal, yaitu 72,15\% dengan IMT kurang dari $23 \mathrm{~kg} / \mathrm{m} 2$ dan 64,6\% presentase lemak kurang dari 22,1 \% (Prathita, Lipoeto, t.t.).

Hasil penelitian memang menunjukkan tidak perbedaan IMT terhadap menstruasi remaja putri, hal tersebut memiliki pola yang sama dengan penelitian Olaf Sianifar yang menyatakan tidak didapatkan hubungan yang bermakna antara IMT dengan siklus menstruasi serta faktor yang mempengaruhi menstruasi adalah usia, kelas serta aktivitas fisik.(Olaf Sianifar, 2009) Obesitas dan stress merupakan faktor yang dapat menyebabkan gangguan menstruasi, sesuai dengan Penelitian Rakhmawati yang menyatakan bahwa Stress dapat menyebabkan gangguan menstruasi $(\mathrm{OR}=1)$ dan obesitas mempengaruhi gangguan siklus menstruasi (OR=2,8) (Rakhmawati \& Dieny, 2013). Sebenarnya siklus haid 28 hari itu tidak terlalu sering dijumpai. hanya sekitar $10-15 \%$ wanita yang memiliki siklus 28 hari. (Wiknjosastro, 2012).

Berdasarkan hasil penelitian diketahui tidak terdapat pengaruh anemia defisiensi besi dan Indeks Massa Tubuh terhadap siklus menstruasi remaja putri baik secara partial atau pun simltan. Nilai overall persentase sebelum variabel independen dimasukkan ke dalam model sebesar: $28 / 60=46,7 \%$ artinya kurang dari 50 persen kemungkinan remaja putri yang mengalami anemia dan IMT tidak normal akan mengalami gangguan siklus menstruasi. Hal tersebut dapat disebabkan karena faktor yang mempengaruhi siklus menstruasi tidak hanya dari status anemia dan indeks massa tubuh.

Faktor yang mempengaruhi siklus menstruasi antara lain aktivitas fisik, stress, merokok, konsumsi obat dan penyakit. hasil penelitian yang dilakukan Baiq menunjukkan bahwa ada hubungan pola makan dengan anemia serta pola menstruasi dengan anemia (Utami \& Mardiyaningsih, 2015).

Menurut penelitian yang dilakukan Nurul menyebutkan terdapat hubungan antara aktivitas fisik dengan siklus menstruasi pada atlet kontingen PON XIX di KONI Sulawesi Selatan (Yani, t.t.). Selain aktivitas fisik, siklus menstruasi juga dipengaruhi oleh stress. Menurut penelitian yang dilakukan oleh Toduho dkk mendapatkan hasil bahwa stress psikologis berhubungan dengan siklus menstruasi (Toduho, Kundre, \& Malara, 2014).

Penelitian yang dilakukan Andriana dkk menunjukkan bahwa adanya hubungan antara usia menarch, IMT dengan siklus menstruasi, sedangkan aktifitas fisik tidak memiliki hubungan yang bermakna dengan siklus menstruasi. Pada remaja putri yang mengalami menarch di usia <12 tahun lebih banyak yang mengalami gangguan siklus menstruasi 
dibandingkan remaja putri yang mengalami menarch di usia 12-14 tahun (Andriana, Aldriana, \& Andria, 2018)

\section{KESIMPULAN}

Berdasarkan hasil penelitian yang telah dilakukan maka dapat disimpulkan bahwa tidak terdapat pengaruh Anemia dan indeks massa tubuh terhadap siklus menstruasi remaja putri. Namun perlu dikaji lebih lanjut tentang pengaruh anemia dan indeks massa tubuh terhadap siklus menstruasi dengan jumlah sampel yang lebih besar serta perlu dikaji tentang faktorfaktor lain yang mempengaruhi siklus menstruasi pada remaja putri.

\section{DAFTAR PUSTAKA}

Andriana, Aldriana, N., \& Andria. (2018). Faktor-Faktor yang Mempengaruhi Siklus Menstruasi pada Mahasiswa di Universitas Pasir Pangaraian. Jurnal Maternity and Neonatal, 2(2), 271-279.

Aramico, B., Siketang, N. W., \& Nur, A. (2016). Hubungan Asupan Gizi, Aktivitas Fisik, Menstruasi Dan Anemia Dengan Status Gizi Pada Siswi Madrasah Aliyah Negeri (MAN) Simpang Kiri Kota Subulussalam. 10.

Grooms, L. P., RN, N. C., Walsh, M., PhD, C. P. N. P., Monnat, L. E., \& MS, R. D. (2013). Treatment of Anemia in the Adolescent Female. Pediatric Annals, 1(36-39). https:/ / www.healio.com/pediatrics/journals/pedann/2013-1-42-

1/\%7B72f08ed6-d01f-4a61-ab68-82c2221d616a\%7D/treatment-of-anemia-in-theadolescent-female

Kristianti, S., \& Wibowo, T. A. (2014). Hubungan Anemia dengan Siklus Menstruasi pada Remaja Putri di SMA Negeri 1 Imogiri, Bantul, Yogyakarta Tahun 2013. 3(1), 6.

Kusumawati, E., Lusiana, N., Mustika, I., Hidayati, S., \& Andyarini, E. N. (2018). The Differences in the Result of Examination of Adolescent Hemoglobin Levels Using Sahli And Digital Methods (Easy Touch GCHb). Journal of Health Science and Prevention, 2(2), 95-99. https:/ / doi.org/10.29080/jhsp.v2i2.128

Mahitala, A. (2015). Hubungan Aktivitas Fisik dengan Gangguan Menstruasi Wanita Pasangan Usia Subur di Desa Temanggung Kecamatan Kaliangkrik Kabupaten Magelang Tahun 2015. Jurnal Kesehatan Masyarakat, 3(3).

Prathita, Y. A., Lipoeto, N. I., \& nd. (t.t.). Hubungan Status Gizi dengan Siklus Menstruasi pada Mahasiswi Fakultas Kedokteran. Dalam Universitas Andalas 6.

Puspita, D. (2014). Hubungan antara Status Gizi dan Siklus Menstruasi pada Remaja Putri. Jurnal Ilmu Kebidanan, Jilid, 3.

Rakhmawati, A., \& Dieny, F. F. (2013). Hubungan Obesitas dengan Kejadian Gangguan Siklus Menstruasi pada Wanita Dewasa Muda (other). Diponegoro University. Riset Kesehatan Dasar. (2010). Laporan Hasil Riset Kesehatan Dasar Tahun 2010. Riset Kesehatan Dasar. (2013). Laporan Hasil Riset Kesehatan Dasar Tahun 2013. 
Santi, D. R., \& Pribadi, E. T. (2018). Menstrual Disorders Condition of Patients Treated at UIN Sunan Ampel's Primary Clinic. Journal of Health Science and Prevention, 2(1), 14-21. https://doi.org/10.29080/jhsp.v2i1.104

Sayes, F. A. (2011). Prevalence of iron deficiency and iron deficiency anemia among females at university stage. Journal of Medical Laboratory and Diagnosis, 2(1), 5-11.

Silalahi, V., Aritonang, E., \& Ashar, T. (2016). Potensi Pendidikan Gizi Dalam Meningkatkan Asupan Gizi Pada Remaja Putri Yang Anemia di Kota Medan. Jurnal Kesehatan Masyarakat, 11 (2), 295. Diakses di laman https:// doi.org/10.15294/kemas.v11i2.4113

Toduho, S., Kundre, R., \& Malara, R. (2014). Hubungan Stres Psikologi dengan Siklus Menstruasi pada Siswi Kelas 1 di SMA Negeri (Vol. 3).

Utami, B. N., \& Mardiyaningsih, E. (2015). Hubungan Pola Makan dan Pola Menstruasi Dengan Kejadian Anemia Remaja Putri. Jurnal Keperawatan Soedirman, 10, 9.

Wiknjosastro, H. (2012). Ilmu Kandungan. Jakarta: Yayasan Bina Pustaka Sarwono Prawirohardjo.

Yani N. G., \& nd. (t.t.). Hubungan Aktivitas Fisik Dengan Siklus Menstruasi Pada Atlet Kontingen. Dalam Pon Xix Jawa Barat Di Koni Sulawesi Selatan 73.

Zufrianingrum, H. (2016). Hubungan Antara Kadar Hemoglobin Dan Kapasitas Vital Paru Dengan Daya Tahan Kardiorespirasi Siswa Yang Mengikuti Ekstrakurikuler Bolabasket Di Smp Negeri 1 Jetis Kabupaten Bantul. Universitas Negeri. Yogyakarta, Yogyakarta. 